Thus the median time for the onset of ovulation was $3.9 \mathrm{~h}$ earlier and the duration $2.8 \mathrm{~h}$ shorter, in mated females, whereas artificial insemination was not effective in inducing earlier ovulation.

The effects of the stimuli associated with mating could be mediated by modifications in the patterns of discharge of pituitary gonadotropins, as a single injection of PMSG similarly reduces the duration of ovulation.

\title{
SYNCHRONISATION DES CHALEURS DES TRUIES NULLIPARES PAH UN TRAITEMENT MÉTHALLIBURE PMSG-HCG. EFFET DE MODIFICATION DES MOMENTS D'INJECTION
}

\author{
F. MARTINAT, J.-P. SIGNORET et F. du MESNIL du BUISSON, \\ Station de Physiologie de la Reproduction, \\ Centre de Recherches de Tours, I. N.R.A., \\ Nouzilly 37380 Monnaie
}

\section{RÉSUMÉ}

Des truies nullipares Large White ou hybride Landrace $\times$ Large White reçoivent $100 \mathrm{mg}$ par jour de méthallibure pendant 20 jours, puis I 000 UI de PMSG et 500 UI de HCG en injection intramusculaire.

Dans une première expérience ( 46 truies) PMSG a été injectée le $\mathrm{J}_{1}$ et HCG soit le $\mathrm{J}_{4}$, soit le $\mathrm{J}_{5}$. La réduction de l'intervalle entre l'injection de PMSG et celle de HCG a tendance à abaisser le taux de groupage des chaleurs $\left(5^{\circ} \mathrm{p}\right.$. Ioo contre $72,0 \mathrm{p}$. I0o), le taux de mise bas $(66,6 \mathrm{p}$. Iо० contre $8 \mathrm{I}, 3$ p. IOO) et la prolificité $(7,9$ contre 9,4$)$.

Dans une deuxième expérience (25 truies) PMSG et HCG ont été injectées à 4 jours d'intervalle soit le $J_{1}$ et le $J_{5}$, soit le $J_{2}$ et le $J_{6}$.

En retardant le moment des injections, on ne constate aucun effet bénéfique.

\section{SUMMARY}

\section{HEAT SYNCHRONIZATION OF NULLIPAROUS SOWS BY A METHALIIBURE} AND PMSG-HCG TREATMENT ; EFFECT OF CHANGING THE MOMENTS OF INJECTION

Nulliparous Large White sows or Landrace $\times$ Large White hybrid sows received $100 \mathrm{mg} /$ day of methallibure during 20 days followed by intramuscular injections od I ooo IU PMSG and 5 Oo IU HCG.

In the first trial (46 sows) PMSG was injected on day I $\left(D_{1}\right)$ and HCG either on $D_{4}$ or $D_{5}$. Reduction of the interval between injection of PMSG and that of HCG tended to lower the rate of heat blocking ( $5 \circ \mathrm{p}$. Ioo versus $72.0 \mathrm{p}$. Ioo), the farrowing rate and the prolificacy. 
In the second trial (25 sows) PMSG and HCG were injected at intervals of 4 days, either $D_{1}$ and $D_{5}$ or $D_{2}$ and $D_{6}$.

Delay in the moment of injections did not bring about any positive effect.

\title{
SYNCHRONISATION DE L'ESTRUS DES TRUIES NULLIPARES PAR EMPLOI D'IMPLANTS DE NORÉTHANDROLONE
}

\author{
F. MARTINAT, F. du MESNIL du BUISSON et P. MAULÉON \\ Station de Physiologie de la Reproduction, \\ Centre de Recherches de Tours, I. N. R. A., \\ Nouzilly 37380 Monnaie
}

\section{RÉSUMÉ}

$8_{4}$ truies nullipares cycliques Large White ou Large White $\times$ Landrace ont reçu un ou deux implants sous-cutanés contenant chacun $25^{\circ} \mathrm{mg}$ de norethandrolone. Le progestagène (I $7 \alpha$ éthylI9 Nortestostérone) est lié à un polymère hydrophile de l'acide métacrylique (hydron).

Les implants sont retirés au bout de 20 jours. Deux à sept jours après le retrait, on constate l'œstrus pour 66,6 et 80,9 p. Ioo des truies ayant eu un ou deux implants.

Le pourcentage de truies gestantes par rapport aux truies venues en œstrus est de $45, \circ \mathrm{p}$. Ioo et de 70,6 p. Ioo respectivement. Une injection de I ooo UI de PMSG le lendemain du retrait de l'implant a eu un effet dépressif sur le pourcentage de truies gestantes. Le taux d'ovulation ( 7,4 à 19,2) est fort dans tous les lots et le nombre d'embryons à 30 jours de gestation est normal (10,2 à I 2,6 ).

La taille des implants $(9 \mathrm{~cm})$ est probablement la cause des pertes nombreuses d'implants.

D'autres essais sont nécessaires pour obtenir un groupage de l'œestrus permettant une insémination artificielle à jour prédéterminé.

\section{SUMMARY}

\section{OESTRUS SYNCHRONIZATION OF NULIIPAROUS SOWS BY IMPLANTS OF NORETHANDROLONE}

84 cyclic nulliparous Large White or Large White $\times$ Landrace sows received one or two subcutaneous implants of $250 \mathrm{mg}$ norethendrolone. The progestagen ( 7 alpha ethyl. I9 nortestosterone) is bound to a hydrophile polymere of metacrylic acid (hydron).

The implants were withdrawn after 20 days. Two to seven days after, return to oestrus was noticed for 66.6 and 80.9 p. Ioo of the sows with one or two implants.

Percentage of pregnant sows compared with sows returned to ostrus was 45.0 and $70.6 \mathrm{p}$. Io respectively. Injection of $I$ ooo IU PMSG the day after the withdrawal of the implant caused fall in the percentage of pregnant sows. The ovulation rate $(17.4-19.2)$ was high in all the groups and the number of embryos after 30 days of gestation was normal (I0.2 - I 2.6). 